\title{
Abiotrophia defectiva knee prosthesis infection: A case report
}

Nadim Cassir ${ }^{1}$, Jean-Charles Grillo ${ }^{2}$, Jean-Noël Argenson ${ }^{2}$, Michel Drancourt ${ }^{1 *}$ and Pierre-Yves Levy ${ }^{1}$

\begin{abstract}
Background: Abiotrophia species have rarely been implicated in osteoarticular infections. We report one case of an A. defectiva knee prosthesis infection.

Case presentation: A 71-year-old man of Italian origin presented with pain and swelling of the knee four years after the implantation of a total knee replacement prosthesis. While standard culturing of the synovial fluid resulted in no isolation of microorganisms, the direct inoculation of the synovial fluid into a rich culture medium resulted in the identification of $A$. defectiva by polymerase chain reaction sequencing. Repeated attempts of culturing microorganisms from blood were negative, and echocardiograms and colonoscopies were unremarkable. Highdose amoxicillin for nine months and a two-stage replacement of the knee prosthesis led to full patient recovery by the time of the 12-month follow-up examination.

Conclusions: Because Abiotrophia spp. are fastidious microorganisms, it is likely that cases of Abiotrophia orthopedic infection are misdiagnosed as culture-negative infections. Direct inoculation of synovial fluids into rich broth medium and further polymerase chain reaction-based detection of culture-negative synovial fluids are key tests for accurate documentation and detection of these infections.
\end{abstract}

\section{Background}

Abiotrophia organisms are nutritionally variant streptococci that form part of the commensal flora of the oral and intestinal mucosae [1]. The detection and identification of Abiotrophia organisms may be hampered by their inability to grow in standard media and their microscopic pleomorphism [1]. Abiotrophia organisms have been grouped into a unique genus separated from the Streptococcus genus based on genetic and phylogenetic analyses, which revealed a low relatedness to other Streptococcus organisms [2,3]. Abiotrophia organisms cause bacteremia and an estimated $4-6 \%$ of all cases of streptococcal endocarditis [2,4]. However, these organisms have rarely been implicated as the causative agents of osteoarticular infections. Indeed, only four cases of orthopedic infections caused by A. defectiva have been published. These cases include two instances of septic arthritis, one case of discitis and sacroiliitis and one case

\footnotetext{
* Correspondence: michel.drancourt@univmed.fr

'Pôle des Maladies Infectieuses et Tropicales, Assistance Publique - Hôpitaux de Marseille et Unité de Recherche sur les Maladies Infectieuses et Tropicales Emergentes, UMR 6236, IRD 198, IFR48, Université de la Méditerranée,

Marseille, France

Full list of author information is available at the end of the article
}

of total knee arthroplasty infection [5-8] (Table 1). Here, we report on a fifth case of A. defectiva osteoarticular infection through the isolation of the organism and the direct detection of $A$. defectiva-specific DNA sequences through polymerase chain reaction (PCR) detection in the synovial fluid.

\section{Case presentation}

A 71-year-old man of Italian origin was admitted to our infectious orthopedic department presenting with chronic (two-year) left knee pain, swelling and decreasing ambulation. He had received a total knee prosthesis for left knee osteoarthritis four years prior. The prosthesis had been replaced twice for radiologically confirmed loosening, with the latest replacement being two years prior to admittance. Cultures of synovial fluid collected during both replacements remained sterile after inoculation of standard solid media. Our patient underwent a dental treatment without antibiotic prophylaxis three weeks before the consultation. Upon physical examination, our patient was found to be apyretic. His left knee was swollen and radiating heat, and a moderately sized effusion was present. His 
Table 1 Cases of orthopedic infection caused by A. defectiva

\begin{tabular}{|c|c|c|c|c|c|c|c|}
\hline Patient & $\begin{array}{l}\text { Age/ } \\
\text { Sex }\end{array}$ & $\begin{array}{l}\text { Dental } \\
\text { procedure }\end{array}$ & Location & $\begin{array}{l}\text { Microbiological } \\
\text { diagnosis }\end{array}$ & Endocarditis & Treatment & Outcome \\
\hline $\begin{array}{l}\text { Patient } 1 \\
\text { [7] }\end{array}$ & $65 / F$ & & $\begin{array}{l}\text { 4-year-old } \\
\text { total knee } \\
\text { arthroplasty }\end{array}$ & $16 S$ rDNA PCR & No & $\begin{array}{l}\text { Cefazolin i.v. } 10 \text { days, ciprofloxacin } \\
\text { orally } 26 \text { days }\end{array}$ & $\begin{array}{l}\text { Relapse four months later: } \\
\text { two-stage revision } \\
\text { arthroplasty, flucloxacillin } \\
\text { orally }\end{array}$ \\
\hline $\begin{array}{l}\text { Patient } 2 \\
{[5]}\end{array}$ & $\begin{array}{l}90 / \\
M\end{array}$ & $\begin{array}{l}\text { two } \\
\text { months } \\
\text { before }\end{array}$ & Knee & $\begin{array}{l}\text { Synovial fluid } \\
\text { cultures, blood } \\
\text { cultures }\end{array}$ & No & $\begin{array}{l}\text { Ceftriaxone i.v., levofloxacin orally six } \\
\text { weeks }\end{array}$ & Improved \\
\hline $\begin{array}{l}\text { Patient } 3 \\
\text { [6] }\end{array}$ & $\begin{array}{l}75 / \\
M\end{array}$ & $\begin{array}{l}\text { one day } \\
\text { before }\end{array}$ & Knee & $\begin{array}{l}\text { Synovial fluid } \\
\text { culture, blood } \\
\text { cultures }\end{array}$ & No & $\begin{array}{l}\text { Penicillin G i.v. and gentamicin i.v. } \\
\text { three weeks, Penicillin G i.v. five } \\
\text { weeks, levofloxacin orally four weeks }\end{array}$ & Improved \\
\hline $\begin{array}{l}\text { Patient } 4 \\
\text { [8] }\end{array}$ & $\begin{array}{l}51 / \\
M\end{array}$ & $\begin{array}{l}\text { six weeks } \\
\text { before }\end{array}$ & $\begin{array}{l}\text { Discitis and } \\
\text { sacroiliitis }\end{array}$ & Blood cultures & Yes & $\begin{array}{l}\text { Amoxicillin i.v., gentamicin i.v. and } \\
\text { rifampicin orally three weeks, } \\
\text { amoxicillin and rifampicin orally } 11 \\
\text { weeks }\end{array}$ & $\begin{array}{l}\text { No relapse (12-month } \\
\text { follow-up) }\end{array}$ \\
\hline $\begin{array}{l}\text { Patient } 5 \\
\text { [this case } \\
\text { report] }\end{array}$ & $\begin{array}{l}71 / \\
M\end{array}$ & $\begin{array}{l}\text { one week } \\
\text { before }\end{array}$ & $\begin{array}{l}\text { 2-year-old } \\
\text { total knee } \\
\text { arthroplasty }\end{array}$ & $\begin{array}{l}\text { 16S rDNA PCR, } \\
\text { synovial fluid } \\
\text { (blood culture } \\
\text { bottles) }\end{array}$ & No & $\begin{array}{l}\text { Two-stage revision arthroplasty. } \\
\text { Amoxicillin orally nine months }\end{array}$ & $\begin{array}{l}\text { No relapse (12- month } \\
\text { follow-up) }\end{array}$ \\
\hline
\end{tabular}

F: female; i.v.: intravenously; M: male

white blood cell count indicated $3.82 \times 10^{3}$ polymorphonuclear cells $/ \mathrm{mL}$, his C-reactive protein (CRP) level was $32 \mathrm{mg} / \mathrm{L}$ and the erythrocyte sedimentation rate (ESR) was $66 \mathrm{~mm}$ (first hour). Our patient was referred to the orthopedic department for sample biopsy and arthroscopic lavage. The synovial fluid was directly inoculated into a set of Bactec Plus Aerobic/F and Bactec Lytic/10 Anaerobic/F bottles (BD Diagnostic Systems, Sparks, MD, USA) and collected in parallel into a sterile tube as part of an "arthritis kit", as previously described [9]. Microscopic examination of the synovial fluid indicated $32 \times 10^{3}$ white blood cells $/ \mathrm{mL}(98 \%$ neutrophil polymorphonuclear cells and $2 \%$ monocytes) and $4.77 \times 10^{3}$ red blood cells $/ \mathrm{mL}$ without crystals. No microorganisms were observed. Inoculation of the synovial fluid onto 5\% sheep-blood agar showed no growth after a five-day incubation period at $37^{\circ} \mathrm{C}$ under a $5 \%$ carbon dioxide $\left(\mathrm{CO}_{2}\right)$ atmosphere. However, the aerobic broth bottle produced Gram-positive cocci after a five-day incubation period at $37^{\circ} \mathrm{C}$ under continuous automated monitoring for bacterial growth in the medium. Subculturing these organisms on 5\% sheep-blood agar and chocolate agar (BioMérieux, Marcy l'Etoile, France) at $37^{\circ} \mathrm{C}$ under a $5 \% \mathrm{CO}_{2}$ atmosphere produced colonies. These colonies were identified as $A$. defectiva by $16 \mathrm{~S}$ rDNA sequencing [10] (99.9\% sequence similarity with the GenBank accession number AY879308); E test testing confirmed the isolate to be broadly susceptible with minimum inhibitory concentration of $0.01 \mathrm{mg} / \mathrm{L}$ for penicillin $\mathrm{G}$ and rifampicin, $0.016 \mathrm{mg} / \mathrm{L}$ for amoxicillin, ceftriaxone and vancomycin, $0.02 \mathrm{mg} / \mathrm{L}$ for imipenem, $0.1 \mathrm{mg} / \mathrm{L}$ for erythromycin and $0.2 \mathrm{mg} / \mathrm{L}$ for doxycycline [11]. PCR- based detection of bacterial DNA using universal $16 \mathrm{~S}$ rDNA primers [10] detected $A$. defectiva DNA in the synovial fluid on the basis of sequence identity to the DNA recovered from the colonies. Three blood cultures incubated under an aerobic atmosphere and one blood culture incubated under an anaerobic atmosphere showed no growth after a five-day incubation period. A transthoracic echocardiography revealed no signs of endocarditis and a colonoscopy was unremarkable. The knee prosthesis was removed, and a temporary cement spacer containing $2 \mathrm{~g}$ vancomycin and $40 \mathrm{~g}$ cement was inserted [12]. Re-implantation of a total knee was delayed because of an intercurrent venal thrombosis without pulmonary embolism. Our patient received $100 \mathrm{mg} / \mathrm{kg} /$ day oral amoxicillin for nine months. The knee pain and swelling subsequently resolved, and the ESR decreased to $22 \mathrm{~mm}$. The oneyear follow-up examination indicated complete wound healing, with no evidence of a recurrence of infection, a white blood cell count within the normal range, a CRP value of $7.1 \mathrm{mg} / \mathrm{L}$ and an ESR of $17 \mathrm{~mm}$.

\section{Discussion}

In our patient, $A$. defectiva knee prosthesis infection was documented by the isolation and culture of the organism from a synovial fluid recovered under sterile procedures and the parallel detection of $A$. defectiva DNA from this specimen. Although only one joint fluid specimen was available for microbiological investigations, no other detection of $A$. defectiva had been made in our laboratory within the eight-week period preceding isolation of the $A$. defectiva strain here reported. Thus, laboratory contamination is unlikely. 
The reported A. defectiva isolate was recovered after the direct inoculation of the synovial fluid into a culture broth as part of our protocol for the diagnosis of prosthetic joint infection using an "arthritis kit" procedure. The arthritis kit contains one Bactec Plus Aerobic/F and one Bactec Plus Anaerobic/F for culturing bacteria, one sterile tube for culturing mycoplasma, spirochetes and 16S rRNA-based PCR and one sterile tube for culturing and PCR-based detection of virus, in addition to the informed consent form and laboratory forms. The parallel inoculation of this same fluid specimen onto agar media failed to culture the organism. This illustrates the well-known fastidious nature of $A$. defectiva and indicates that the direct inoculation of the synovial fluid into broth is mandatory for the culture-based diagnosis of $A$. defectiva articular infections. The same holds true for the culture-based diagnosis of arthritis caused by Kingella kingae in children [13].

In this patient, the $A$. defectiva infection was documented shortly after a dental procedure without antibiotic prophylaxis. However, this dental procedure was most likely not the portal of entry for A. defectiva, as our patient had presented clinical signs of knee prosthesis infection long before the dental procedure. A prospective case-control study indicated that dental procedures were not risk factors for orthopedic prosthetic infection [14]. Indeed, antibiotic prophylaxis before dental interventions in patients with knee arthroplasty lacks evidence-based recommendations [15].

Our patient had a history of repeated early prosthesis loosening, a situation evocative of chronic infection of the prosthesis [16,17]. Tentative documentations remained negative, but these diagnoses lacked direct inoculation of the synovial fluid into broth and molecular detection. Therefore, the loosening episodes of the two prostheses may have been due to a chronic A. defectiva infection.

The fastidious nature of $A$. defectiva may explain the rarity of $A$. defectiva orthopedic infections, and cases of Abiotrophia infection may be misdiagnosed as culturenegative infections. Accordingly, the role of Abiotrophia organisms in osteoarticular infections may be underestimated. A review of the literature indicates that only one case of an orthopedic prosthesis Abiotrophia infection has been published, and $A$. defectiva joint infection has been reported in only four cases (Table 1).

\section{Conclusion}

In conclusion, this case illustrates the effectiveness of the "arthritis kit" procedure. By incorporating a systematic direct inoculation of the synovial fluid into broth along with a parallel PCR-based detection of fastidious microorganisms, the diagnosis of orthopedic prosthesis infections, such as those caused by Abiotrophia spp., can be optimized.

\section{Consent}

Written informed consent was obtained from the patient for publication of this case report. A copy of the written consent is available for review by the Editor-in-Chief of this journal.

\section{Author details}

'Pôle des Maladies Infectieuses et Tropicales, Assistance Publique - Hôpitaux de Marseille et Unité de Recherche sur les Maladies Infectieuses et Tropicales Emergentes, UMR 6236, IRD 198, IFR48, Université de la Méditerranée, Marseille, France. ${ }^{2}$ Service de Chirurgie Orthopédique, Hôpital SainteMarguerite, Assistance Publique - Hôpitaux de Marseille, France.

\section{Authors' contributions}

NC took care of the patient and wrote the manuscript. JCG took care of the patient, reviewed and corrected the manuscript. JNA took care of the patient, reviewed and corrected the manuscript. MD took care of the patient and wrote the manuscript. PYL conceived the study and wrote the manuscript. All authors read and approved the final manuscript.

\section{Competing interests}

The authors declare that they have no competing interests.

Received: 28 March 2011 Accepted: 6 September 2011

Published: 6 September 2011

\section{References}

1. Ruoff KL: Nutritionally variant streptococci. Clin Microbiol Rev 1991, 4:184-190.

2. Senn L, Entenza JM, Greub G, Jaton K, Wenger A, Bille J, et al: Bloodstream and endovascular infections due to Abiotrophia defectiva and Granulicatella species. BMC Infect Dis 2006, 6:9.

3. Christensen JJ, Facklam RR: Granulicatella and Abiotrophia species from human clinical specimens. J Clin Microbiol 2001, 39:3520-3523.

4. Brouqui P, Raoult D: Endocarditis due to rare and fastidious bacteria. Clin Microbiol Rev 2001, 14:177-207.

5. O'Connor KM, Williams P, Pergam SA: An unusual case of knee pain: pseudogout and Abiotrophia defectiva infection. South Med J 2008, 101:961-962.

6. Taylor CE, Fang MA: Septic arthritis caused by Abiotrophia defectiva. Arthritis Rheum 2006, 55:976-977.

7. Ince A, Tiemer B, Gille J, Boos C, Russlies M: Total knee arthroplasty infection due to Abiotrophia defectiva. J Med Microbiol 2002, 51:899-902.

8. Wilhelm N, Sire S, Le Coustumier A, Loubinoux J, Beljerd M, Bouvet A: First case of multiple discitis and sacroiliitis due to Abiotrophia defectiva. Eur J Clin Microbiol Infect Dis 2005, 24:76-78.

9. Fenollar F, Levy PY, Raoult D: Usefulness of broad-range PCR for the diagnosis of osteoarticular infections. Curr Opin Rheumatol 2008, 20:463-470.

10. Weisburg WG, Barns SM, Pelletier DA, Lane DJ: 16 S ribosomal DNA amplification for phylogenetic study. J Bacteriol 1991, 173:697-703.

11. Jorgensen JH, Hindler JF: New consensus guidelines from the clinical and laboratory Standards Institute for antimicrobial susceptibility testing of infrequently isolated or fastidious bacteria. Clin Infect Dis 2007, 44:280-286.

12. Seyral $P$, Zannier $A$, Argenson $J N$, Raoult $D$ : The release in vitro of vancomycin and tobramycin from acrylic bone cement. J Antimicrob Chemother 1994, 33:337-339.

13. Yagupsky P: Kingella kingae: from medical rarity to an emerging paediatric pathogen. Lancet Infect Dis 2004, 4:358-367.

14. Berbari EF, Osmon DR, Carr A, Hanssen AD, Baddour LM, Greene D, et al: Dental procedures as risk factors for prosthetic hip or knee infection: a hospital-based prospective case-control study. Clin Infect Dis 2010, 50:8-16. 
15. Uçkay I, Pittet D, Bernard L, Lew D, Perrier A, Peter R: Antibiotic prophylaxis before invasive dental procedures in patients with arthroplasties of the hip and knee. J Bone Joint Surg Br 2008, 90:833-838.

16. Mortazavi SM, Schwartzenberger J, Austin MS, Purtill JJ, Parvizi J: Revision total knee arthroplasty infection: Incidence and predictors. Clin Orthop Relat Res 2010, 468:2052-2059.

17. Gonzalez MH, Mekhail AO: The failed total knee arthroplasty: evaluation and etiology. J Am Acad Orthop Surg 2004, 12:436-446.

doi:10.1186/1752-1947-5-438

Cite this article as: Cassir et al:: Abiotrophia defectiva knee prosthesis infection: A case report. Journal of Medical Case Reports 2011 5:438.

Submit your next manuscript to BioMed Central and take full advantage of:

- Convenient online submission

- Thorough peer review

- No space constraints or color figure charges

- Immediate publication on acceptance

- Inclusion in PubMed, CAS, Scopus and Google Scholar

- Research which is freely available for redistribution

Submit your manuscript at www.biomedcentral.com/submit 